\title{
A review: the prevalence of dermatophytosis on cats in Indonesia and Turkey
}

\author{
Fatin Hanani Md Zaki ${ }^{1}$, Claude Mona Airin ${ }^{2}$, Alfarisa Nururrozi $^{3}$, Yanuartono ${ }^{3}$, and \\ Soedarmanto Indarjulianto ${ }^{3 *}$ \\ ${ }^{1}$ Faculty of Veterinary Medicine, Universitas Gadjah Mada, Jl. Fauna 2, Karangmalang, Yogyakarta \\ 55281, Indonesia. \\ ${ }^{2}$ Department of Physiology, Faculty of Veterinary Medicine, Universitas Gadjah Mada, Jl. Fauna 2, \\ Karangmalang, Yogyakarta 55281, Indonesia. \\ ${ }^{3}$ Department of Internal Medicine, Faculty of Veterinary Medicine, Universitas Gadjah Mada, Jl. \\ Fauna 2, Karangmalang, Yogyakarta 55281, Indonesia
}

\begin{abstract}
Dermatophytosis (ringworm) is an important feline skin disease primarily caused by the dermatophyte genera Microsporum and Trichophyton which may be affected by climate. Studying the prevalence of dermatophytosis on cats in Indonesia and Turkey was the main purpose of this article review. The articles reviewed were two articles from Turkey published consecutively on year 2011 and 2016, and an article from Indonesia published on year 2017. The findings showed that the prevalence of dermatophytosis in Indonesia was $17 / 30(56.7 \%)$ while Turkey was $52 / 428(12.1 \%)$. The age of the infected animals was the only predictor that had a major effect on the incidence of dermatophytosis on cats, as shown by the excellent positive cases of cats under one year of age relative to other age groups. In conclusion, the prevalence of dermatophytosis on cats in Turkey was slightly lower compared to the prevalence of feline dermatophytosis in subtropical country (Indonesia) and the variations may be attributed to the variation in humidity and temperature faced in both countries.
\end{abstract}

\section{Introduction}

Dermatophytosis or commonly known as ringworm is a fungal infection on the superficial layer of the skin primarily caused by dermatophytes that have the capability to invade the stratum corneum of the epidermis and the keratinized tissues such as nails and hairs of the infected animals [1-2]. While feline dermatophytosis is clinically mild and self-limiting, this disease has caused concern because it is highly contagious, zoonotic and environmentally difficult [3]. Microsporum canis were the most isolated pathogen of the dermatophytepositive cats while other species such as Microsporum gypseum, Microsporum pericolor and Trichophyton sp. have been recorded but rarely isolated [4].

Feline dermatophytosis is a worldwide disease and is generally diagnosed in this species. Dermatophytes can not only be isolated from a symptomatic cat that had skin lesions, but

*Corresponding author: indarjulianto@ugm.ac.id 
also from fomite carriers or an asymptomatic cats. Dermatophyte arthrospores may be spread directly from infected cats or passively when healthy cats have indirect contact with contaminated collars, toys, brushes, environments or socializing with asymptomatic cats. Owing to the adhesion of the arthrospores to the hair shaft, the pathogen is easily transferred from one location to another [4].

Previously, [3] concluded that based on several studies, cats seem to be more vulnerable towards dermatophytes when they aged younger than one year old, cats with long-haired coats, Persian breeds, cats diagnosed with feline immunodeficiency virus (FIV) and few exposure factors such as cats living in cattery or shelters or living outside, warm or humid climate and warm season. Humidity and temperature are examples of environmental factors that give the dermatophytes a beneficial atmosphere to grow and infect hosts. Depending on the country to country and region to region within a country, the prevalence of feline dermatophytosis and the most isolated pathogen may vary [5].

The prevalence of dermatophytosis in cats in tropical countries with constant temperature and humidity over the years is substantially higher compared to countries with four seasons that cause changes in humidity and temperature over the year. It is therefore important to research and find more information on the prevalence of dermatophytosis in cats in a country of four seasons and a tropical country in order to identify potential predisposing factors to the prevalence of the incident. The goal of this study is to determine the prevalence of dermatophytosis in Indonesia and Turkey and possible predisposing factors.

\section{Materials and Methods}

This study was performed in the context of a retrospective study using one Indonesian and two Turkish research papers based on the occurrence of cases of dermatophytosis in cats. The articles used were from Seker and Dogan (2011), Ilhan et al. (2016) and Indarjulianto et al. (2017). The variables taken into account were the age (younger than 1 year, 103 years and older than 3 years) and sex (male and female) of the animals sampled and the season at which sampling was carried out (spring, summer, fall and winter). The data collected was analyzed, categorized and tabulated using Microsoft Excel 2013 in order to be well aware of the prevalence of dermatophytosis in cats based on the variables observed. Shortly thereafter, the cumulative data were compiled and addressed descriptively.

\section{Results and Discussion}

The study consisted of two papers from Turkey containing 428 samples, 164 samples from Seker and Dogan (2011) and 264 samples from Ilhan et al. (2016). The findings of this study showed that the prevalence of feline dermatophytosis in Turkey was 52/428 (12.1\%) (Table 1). Based on the season of sampling, the prevalence of feline dermatophytosis in cats was $22 / 127(17.3 \%)$ in spring, $11 / 93(11.8 \%)$ in fall, $11 / 96(11.5 \%)$ in winter and 8/112 (7.1\%) in summer (Table 2). Compared to the Indonesian research by Indarjulianto et al. (2017), the prevalence of feline dermatophytosis in Turkey was 4.7 times lower than in Indonesia (17/30 : $56.7 \%$ ) (Table 1). This disparity can be due to many factors, including heat and humidity. High moisture was required by the dermatophytes to develop and infect the skin as they rely solely on the keratinized layer of the skin and have to be intact with the organ without being removed from the skin. In a humid environment, water means that the skin is still moist and does not have to be shed, whereas the dryness of the epidermis discourages skin infection with dermatophytes. According to [6], there are several predisposing factors that promote dermatophyte development, including local factors such as heat and moisture. 
According to [5], the prevalence of feline dermatophytosis in Malaysia was 27/155; $17.4 \%$, in India was $103 / 292 ; 35.7 \%$ [7], and in Indonesia was $17 / 30 ; 56.7 \%$ [8] showed a consistent, relatively high prevalence of feline dermatophytosis in tropical countries. On the other hand, the prevalence of dermatophytosis among cats in temperate countries such as the United States of America was 45/1407; 3.2\% [9], Ukraine was 615/1124; 50.3\% [10], and Turkey was $52 / 428 ; 12.1 \%$ [11-12] showed a marked difference in prevalence especially Ukraine that had a noticeable higher prevalence compared to other temperate countries that can be affected by selection of samples showing clinical signs leading to dermatophytosis.

Table 1. The total prevalence of dermatophytes in cats in Indonesia and Turkey.

\begin{tabular}{|c|c|c|c|}
\hline \multirow{2}{*}{$\begin{array}{c}\text { Countrie } \\
\text { s }\end{array}$} & Sources & \multicolumn{2}{|c|}{ Prevalence } \\
\cline { 3 - 4 } & & $\begin{array}{c}\text { No. positive } \\
\text { animal/ No. } \\
\text { animal tested }\end{array}$ & $\%$ \\
\hline Turkey & Seker and Dogan (2011) & $33 / 164$ & 20.1 \\
\hline & 16 Ilhan et al. (2016) & $19 / 264$ & 7.2 \\
\hline & Total & $52 / 428$ & 12.1 \\
\hline Indonesia & Indarjulianto et al. (2017) & $17 / 30$ & 56.7 \\
\hline
\end{tabular}

Turkey is a country that has undergone four seasons (spring, summer, fall and winter) and caused a relative shift in weather during these four seasons. Turkey has a dry continental climate with cold snowy winters and warm dry summers, with drastic temperature variations as low as $-2.2^{\circ} \mathrm{C}$ during the winter and above $30^{\circ} \mathrm{C}$ during the summer months. Rainfall occurs mainly during spring and autumn, with average annual rainfall ranging from approximately $300 \mathrm{~mm}$ to $700 \mathrm{~mm}$, based on regions with relative humidity of approximately $59 \%$ [11-12], while Indonesia is a tropical country that is typically hot and humid throughout the year, characterized by two seasons: dry and rainy seasons. Throughout the rest of the country, the year-round temperatures at sea level range from about $20^{\circ} \mathrm{C}$ to $32^{\circ} \mathrm{C}$ and the average humidity is between $75 \%$ and $85 \%$ [13].

Most dermatophytes grow at temperatures between $25^{\circ} \mathrm{C}$ and $35^{\circ} \mathrm{C}$ and, in accordance with studies conducted by [14], $33^{\circ} \mathrm{C}$ was the optimum temperature for the growth of Trichophyton rubrum. Dermatophytosis is most common in hot, humid environments [15]. The shedding of epidermal cells is one of the defence mechanisms of the skin that prevents any invasion of the dermatophytes and prevents several microbes from taking up residence. By raising the temperature and humidity of the environment, the occlusion of dermatophytes on the skin would not be stopped by the skin barrier and the defence mechanism would fail ([16]. In this analysis, the prevalence of feline dermatophytosis in Turkey was the lowest during the summer, although the temperature during this season was still higher than in other seasons. This may be attributed to low humidity during the summer due to lack of rainfall, resulting in warm dry summers [11-12].

Based on the age of the sampled animals, the prevalence of feline dermatophytosis in this study from the highest to the lowest was 36/181 (19.9\%) for cats younger than one year, $9 / 136(6.6 \%)$ for cats between one and three years of age, and 7/111 (6.3\%) for cats older than three years of age (Table 2). As reported by [17], 11/17 (64.7\%) of dermatophytepositive cats were younger than one year, while $[3,18]$ reported that cats aged 6 months and younger were more likely to have greater prevalence. Increased susceptibility to 
dermatophytosis in kittens can be impaired by a variety of causes, including immaturity of the immune system, insufficiency of past immunity, skin micro trauma induced by siblings or ectoparasites, and frequent close contact with other cats during socialization [3, 17]. The present study found a moderately higher incidence of dermatophytes $(13.4 \%)$ in female cats than in male cats $(10.7 \%)$, as compared to a study in Eastern India that recorded a higher prevalence of male cats than female cats and the disparity in prevalence between female and male cats may be due to unequal number of samples of each sex [7]. However, some studies have claimed that sex is not a major factor in the occurrence of dermatophytosis in cats $[7$, 19-20].

Table 2. The total prevalence of dermatophytes in cats in Indonesia and Turkey.

\begin{tabular}{|c|c|c|c|c|c|c|}
\hline \multirow[b]{2}{*}{ Variables } & \multicolumn{2}{|c|}{$\begin{array}{c}\text { Seker and Dogan } \\
\text { (2011) }\end{array}$} & \multicolumn{2}{|c|}{ Ilhan et al. (2016) } & \multicolumn{2}{|l|}{ Total } \\
\hline & $\begin{array}{l}\text { No. positive } \\
\text { animal/ No. } \\
\text { animal } \\
\text { tested }\end{array}$ & $\%$ & $\begin{array}{c}\text { No. positive } \\
\text { animal/ No. } \\
\text { animal } \\
\text { tested }\end{array}$ & $\%$ & $\begin{array}{l}\text { No. positive } \\
\text { animal/ No. } \\
\text { animal tested }\end{array}$ & $\%$ \\
\hline \multicolumn{7}{|l|}{ Season } \\
\hline Spring & $11 / 47$ & 23.4 & $11 / 80$ & $\begin{array}{c}13 . \\
8\end{array}$ & $22 / 127$ & 17.3 \\
\hline Summer & $7 / 31$ & 22.6 & $1 / 81$ & 1.2 & $8 / 112$ & 7.1 \\
\hline Fall & $10 / 49$ & 20.4 & $1 / 44$ & 2.2 & $11 / 93$ & 11.8 \\
\hline Winter & $5 / 37$ & 13.5 & $6 / 59$ & $\begin{array}{c}10 . \\
2\end{array}$ & $11 / 96$ & 11.5 \\
\hline \multicolumn{7}{|l|}{ Age } \\
\hline$<1$ years & $25 / 63$ & 39.7 & $11 / 118$ & 9.3 & $36 / 181$ & 19.9 \\
\hline $1-3$ years & $5 / 58$ & 8.6 & $4 / 78$ & 5.1 & $9 / 136$ & 6.6 \\
\hline$>3$ years & $3 / 43$ & 7.0 & $4 / 68$ & 5.9 & $7 / 111$ & 6.3 \\
\hline \multicolumn{7}{|l|}{ Sex } \\
\hline Female & $18 / 87$ & 20.7 & $13 / 145$ & 9.0 & $31 / 232$ & 13.4 \\
\hline Male & $15 / 77$ & 19.5 & $6 / 119$ & 5.0 & $21 / 196$ & 10.7 \\
\hline
\end{tabular}

\section{Conclusions}

The prevalence of dermatophytosis in cats in Turkey represented by the articles reviewed was substantially lower than in the tropical country of Indonesia. Differences may be due to the variation in humidity and temperature encountered in both countries. It is important to remember that high humidity and temperature play a role in helping the dermatophytes develop and cause infection in hosts. As a result, a four season country like Turkey is more likely to have a lower incidence of feline dermatophytoss compared to a tropical country with high humidity and temperatures over the years. 


\section{References}

1. M. Pasquetti, A. R. M. Min, S. Scacchetti, A. Dogliero, A. Peano, Vet. Sci. 4, 46 (2017)

2. R. Stuntebeck, K. A. Moriello, M. Verbrugge, JFMS (2017)

3. L. G. DeTar, V. Dubrovsky, J. M. Scarlett, JFMS (2019)

4. W. G. Abdalla, SAJRM 1, 4 (2018)

5. N. Fazliyana, K. Tiwari, Asian J. Biol. Sci. 12, 2 (2019)

6. A. Carvalho, Immunogenetics of Fungal Diseases (Springer, Switzerland, 2017)

7. C. Debnath, T. Mitra, A. Kumar, I Samanta, IJVR 17, 1 (2016)

8. S. Indarjulianto, Yanuartono, S. Widyarini, S. Raharjo, H. Purnamaningsih, A. Nururrozi, N. Haribowo, H. A. Jainudin, Jurnal Veteriner 18, 2 (2017)

9. D. W. Scott, W. H. Hiller, H. N. Erb, JFMS (2012)

10. G. V. Ponomarenko, V. L. Kovalenko, O. V. Ponomarenko, R. V. Severyn, A. M. Gontar, V. I. Shostak, A. M. Strashnenko, O. O. Humeniuk, O. O. Andriienko, J. Vet. Med. Biotechnol. Biosafety 5, 1 (2019)

11. E. Seker, N. Dogan, Prev. Vet. Med. 98 (2011)

12. Z. Ilhan, M. Karaca, I. H. Ekin, H. Solmaz, H. A. Akkan, M. Tutuncu, Braz. J. Microbiol. 47 (2016)

13. L. C. Cassanos, Major Muslim Nations: Indonesia (Mason Crest Publishers, Broomall, (2010)

14. Sharma, M. Sharma, J. Exp. Sci. 23 (2009)

15. C. E. Greene, Infectious Diseases of the Dog and Cat (ELSEVIER, Missouri, 2012)

16. B. L. Hainer, Am Fam Physician 67, 1 (2003)

17. R. S. Ovchinnikov, V. A. Savinov, A. A. Gaynullina, A. V. Kapustin, A. I. Laishevtsev, IOP Conf. Ser.: Earth Environ. Sci. 421, 8 (2020)

18. K. A. Moriello, R. Stuntebecek, L. Mullen, JFMS (2019)

19. D. Proverbio, R. Perego, E. Spada, G. B. de Giorgi, A. D. Pepa, E. Ferro, Vet. Med. Int. (2014)

20. C. Nitta, A. E. Santana, C. P. Taborda, ActaScientiae Veterinariae 44, 1421 (2016) 